\title{
Efficacy of canakinumab in biologic-naïve versus previously biologic-exposed SJIA patients: a 12 week pooled post-hoc analysis
}

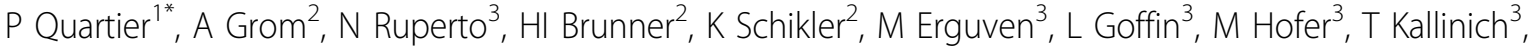 \\ K Marzan ${ }^{2}$, C Gaillez ${ }^{4}$, K Lheritier $^{4}$, K Abrams $^{5}$, A Martini $^{3}$, DJ Lovell ${ }^{2}$
}

From 21st European Pediatric Rheumatology (PReS) Congress

Belgrade, Serbia. 17-21 September 2014

\section{Introduction}

Canakinumab (CAN), a selective, human anti-IL-1 $\beta$ monoclonal antibody is approved for SJIA in over 30 countries. Efficacy and safety of CAN over 12 weeks have been demonstrated in 2 phase III trials [1]. Out of these trials $>60 \%$ of the pts received a previous biologic and were switched to CAN due to lack of efficacy or for safety reasons, and may be more refractory to another biologic therapy.

\section{Objectives}

To present a post-hoc evaluation of CAN efficacy in biologic-naïve (BN) pts and those previously exposed to biologics (BE) during the first 12-weeks.

\section{Methods}

Pooled data from CAN naïve pts, enrolled in two phase III trials $^{1}$ and an extension phase (up to interim data lock 10 August 2012) were considered. Pts (2-19 yrs) with active SJIA were enrolled and received CAN $4 \mathrm{mg} / \mathrm{kg}$ or placebo sc every 4 weeks for 12 weeks. CAN naïve pts who entered the trials and received at least one dose of CAN were included in this analysis ( $\mathrm{N}=178$ CAN naïve pts). Descriptive efficacy analyses of adapted ACR-JIA responses at Week 12 are provided for the $\mathrm{BN}$ and $\mathrm{BE}$ pts groups.

\section{Results}

At baseline, there were 66 (37\%) BN pts whereas anakinra (ANA), tocilizumab (TCZ), etanercept (ETN) and adalimumab (ADA), were the biologics received by 78 (44\%),

${ }^{1}$ Necker-Enfant Malades Hospital, Paris, France

Full list of author information is available at the end of the article
$10(6 \%), 58$ (33 \%) and $9(5 \%)$ pts, respectively. The main reasons for discontinuation of biologics in $\mathrm{BE}$ group $(\mathrm{n}=112)$ was lack of efficacy (ANA, $\mathrm{n}=32 ; \mathrm{TCZ}, \mathrm{n}=7$; ETN, $n=56 ; A D A, n=9$ ) or safety/tolerability (ANA, $n=20$; TCZ, $\mathrm{n}=4$, ETN, $\mathrm{n}=0$ ). At Week 12, the $\mathrm{BN}$ and $\mathrm{BE}$ groups were similar in aACR-JIA 30 and 50 response rates (Week 2: aACR-JIA 30 : $80 \%$ vs $80 \%$; aACR-JIA 50 : $76 \%$ vs $67 \%$; Week 12: aACR-JIA 30: $76 \%$ vs $67 \%$; aACR-JIA $50: 74 \%$ vs $65 \%)$. Numerically higher aACR-JIA 70 and 90 response rates were achieved in $\mathrm{BN}$ vs. BE pts (Week 2: aACR-JIA 70: $67 \%$ vs $52 \%$; aACR-JIA 90 : $36 \%$ vs $37 \%$; Week 12 : aACR-JIA 70 : $70 \%$ vs $55 \%$; aACR-JIA 90 : $61 \%$ vs $42 \%$ ). aACR-JIA 70 and 90 response rates were similar in pts previously exposed to ANA vs those not exposed to ANA at 12 weeks (aACR-JIA70: 58\% vs.63\%; aACR-JIA 90:47\% vs $50 \%$ ). Compared to pts who discontinued ANA due to lack of efficacy, there was a trend towards higher aACRJIA 70 and 90 response rates at Week 12 in pts who stopped ANA for other reasons (aACR-JIA70: $34 \%$ vs.74\%; aACR-JIA90: $25 \%$ vs. $63 \%$ ). A higher aACR-JIA 30, 50, 70 and 90 response rates were observed in TCZ naïve pts vs. those pts exposed to TCZ $(\mathrm{n}=10)$ [aACR-JIA30: 71\% vs.50\%; aACR-JIA50: $70 \%$ vs. $50 \%$; aACR-JIA70: $61 \%$ vs.50\%; aACR-JIA90: $49 \%$ vs. $40 \%$ ]. Higher aACR-JIA 70 and 90 responses were observed for ETN naïve pts vs. those exposed to ETN [aACR-JIA70: $67 \%$ vs. $48 \%$; aACRJIA90: $58 \%$ vs. $31 \%$ ]; while ADA- naïve pts had similar responses to CAN as ADA-exposed pt (aACR-JIA 70: $61 \%$ vs $56 \%$ ) and they had higher aACR-JIA 90 response (aACR-JIA90: $50 \%$ vs. $22 \%$ ).

\section{Conclusion}

In general, pts previously exposed to biologics achieved aACR-JIA 50,70 and 90 responses to CAN quickly in 
the first 2 weeks, and maintained their response up to Week 12; albeit at a numerically lower level than biologicnaïve pts. These data support the consistent efficacy of CAN across different subgroups of pts.

\section{Disclosure of interest}

P. Quartier Grant / Research Support from: Abbvie, BMS, Chugai-Roche, Novartis, Pfizer and SOBI, Consultant for: Abbvie, Chugai-Roche, Novartis, Pfizer, Servier and SOBI, Speaker Bureau of: Chugai-Roche, MEDIMMUNE, Novartis, Pfizer, A. Grom Consultant for: Novartis, Roche, NovImmune, N. Ruperto Grant / Research Support from: To Gaslini Hospital: Abbott, Astrazeneca, BMS, Centocor Research \& Development, Eli Lilly and Company, "Francesco Angelini", Glaxo Smith \& Kline, Italfarmaco, Novartis, Pfizer Inc., Roche, Sanofi Aventis, Schwarz Biosciences GmbH, Xoma, Wyeth Pharmaceuticals Inc., Speaker Bureau of: Astrazeneca, Bristol Myers and Squibb, Janssen Biologics B.V.,Roche, Wyeth/Pfizer, H. Brunner Consultant for: Novartis, Genentech, Pfizer, UCB, AstraZeneca, Biogen, Boehringer-Ingelheim, Regeneron, Paid Instructor for: Novartis, Speaker Bureau of: Novartis, Genentech, K. Schikler Grant / Research Support from: Pfizer, Novartis, Abbvie, Roche, Genentech, Forest, Speaker Bureau of: Abbvie, Novartis, M. Erguven: None declared., L. Goffin Consultant for: Novartis, Pfizer , M. Hofer Grant / Research Support from: Novartis, Pfizer, Abbvie, T. Kallinich Grant / Research Support from: Novartis, Speaker Bureau of: Roche, Novartis, ALK, K. Marzan Grant / Research Support from: Novartis, C. Gaillez Employee of: Novartis, K. Lheritier Shareholder of: Novartis, Employee of: Novartis, K. Abrams Shareholder of: Novartis, Employee of: Novartis, A. Martini Grant / Research Support from: The Gaslini Hospital, which is the public Hospital where I work as full time employee, has received contributions to support the PRINTO research activities from the following companies: Bristol Myers and Squibb, Centocor Research \& Development, Glaxo Smith \& Kline,Novartis,Pfizer Inc, Roche, Sanofi Aventis, Schwarz Biosciences GmbH , Speaker Bureau of: Abbott, Bristol MyersSquibb, Astellas, Behringer, Italfarmaco, MedImmune, Novartis, NovoNordisk, Pfizer, Sanofi,Roche, Servier, D. Lovell Grant / Research Support from: National Institutes of Health- NIAMS , Consultant for: Astra-Zeneca, Centocor, Amgen, Bristol Meyers Squibb, Abbott, Pfizer, Regeneron, Roche, Novartis, UBC, Forest Research Institute, Horizon, Johnson \& Johnson, Speaker Bureau of: Novartis, Roche

\section{Authors' details}

${ }^{1}$ Necker-Enfant Malades Hospital, Paris, France. ${ }^{2}$ PRCSG, Cincinnati, OH, USA ${ }^{3}$ PRINTO-Istituto Gaslini, Genova, Italy. ${ }^{4}$ Novartis Pharma, Basel, Switzerland. ${ }^{5}$ Novartis Pharmaceutical Corporation, NJ, USA.
Published: 17 September 2014

\section{Reference}

1. Ruperto N, et al: N Engl J Med 2012, 367(25)

doi:10.1186/1546-0096-12-S1-P66

Cite this article as: Quartier et al: Efficacy of canakinumab in biologicnaïve versus previously biologic-exposed SJIA patients: a 12 week pooled post-hoc analysis. Pediatric Rheumatology 2014 12(Suppl 1):P66.
Submit your next manuscript to BioMed Central and take full advantage of:

- Convenient online submission

- Thorough peer review

- No space constraints or color figure charges

- Immediate publication on acceptance

- Inclusion in PubMed, CAS, Scopus and Google Scholar

- Research which is freely available for redistribution

Submit your manuscript at www.biomedcentral.com/submit 